\title{
PELAKSANAAN FUNGSI HUKUM ADMINISTRASI NEGARA DALAM MEWUJUDKAN PEMERINTAHAN YANG BAIK
}

\author{
Abid Zamzami \\ Fakultas Hukum Universitas Isalam Malang \\ Jl. Mayjen Haryono Gg. 10 No.193, Dinoyo, Kec. Lowokwaru, Kota Malang, Jawa Timur \\ Email: abid_zamzami@unisma.ac.id
}

\begin{abstract}
The establishment of a country must have a purpose to be achieved, not a single state is formed without a purpose. Indonesia is created with a purpose and one of the goals of the country is to improve the nation. Therefore the state agency in carrying out its duties and functions must realize one of the objectives of the Indonesian nation set forth in the introduction of the 1945 Constitution. in order not to get arbitrary treatment from state officials.
\end{abstract}

Keywords: State, State Administration Law, Legal Protection

\begin{abstract}
ABSTRAK
Berdirinya suatu negara pasti ada suatu tujuan yang ingin dicapai, tidak ada satupun negara yang dibentuk tanpa memiliki suatu tujuan. Negara Indonesia dibentukpun memiliki suatu tujuan dan salah satu tujuan negara ada mensejahterakan bangsa. Oleh karena itu lembaga negara dalam menjalankan tugas dan fungsinya harus memujudkan salah satu dari tujuan bangsa Indonesia yang tercantum dalam pembukaan UUD 1945. Maka keberadaan hukum administrasi negara adalah untuk dijadikan pedoman bagi penyelenggara negara dalam menjalankan tugas dan kewenangannya dan bagi warga negara akan memberikan perlindungan hukum agar tidak mendapatkan perlakuan sewenang-wenang dari pejabat negara
\end{abstract}

Kata Kunci : Negara, Hukum Administrasi Negara, Perlindungan Hukum

\section{PENDAHULUAN}

Pemikiran tentang negara hukum telah muncul jauh sebelum terjadinya Revolusi 1688 di Inggris dan pernah tidak digunakan namun muncul kembali pada abad XVII dan mulai populer pada abad XIX. Latar belakang timbulnya pemikiran negara hukum itu merupakan reaksi terhadap kesewenganwenangan di masa lampau. Oleh karena itu unsur-unsur negara hukum mempunyai hubungan yang erat dengan sejarah dan perkembangan masyarakat dari suatu bangsa. ${ }^{1}$
Negara sebagai suatu organisasi kekuasaan telah menempatkan posisi yang sentral dalam alam kehidupan kolektif manusia modern. Negara tidak hanya dipandang lagi sebagai suatu entitiy yang absolut, dimana semua stakeholder pendukung adanya negara harus tunduk secara mutalk terhadap (penguasa) negara tanpa reserve. ${ }^{2}$ Akan tetapi, justru sebaliknya negara harus mengikuti irama total dari semua elemen pembentuk negara, khususnya rakyat atau warga dari negara yang bersangkutan. Kecenderungan ini telah menjadi konsekuensi dari apresiasi dan

\footnotetext{
Ni'matul Huda, (2005), Negara Hukum, Demokrasi dan Judicial Review, Yogyakarta, UII Press, hlm 1.

2 I Gede Pantja Astawa, (2015), Memahami Ilmu Negara dan Teori Negara, Bandung: PT Refika Aditama, hlm 1 
sekaligus resistensi umat manusia itu sendiri terhadap negara yang sudah dianggap ketinggalan zaman, karena eksistensinta yang telah mencengkram kebebasan tertinggi manusia, hak-hak warga negara seakan-akan telah diambil alih oleh negara sejak negara itu terbentuk. $^{3}$

Haruskah demikian adanya? Tentu pertanyaan ini harus dijawab “ tidak”. Negara pada hakikatnya justru lebih mempermudah interaksi manusia sebagai warga negara, yang tertib, aman, nyaman dan bahkan lebih dari itu harus mampu mensejahterahkan raknyatnya. Negara dalam hal ini harus menjadi sarana warga negaran untuk mencapai tujuan-tujuan hidup manusia dalam masyarakat bangsa, misalnya menjamin keamanan, keadilan dan kesejahteraan tertinggi rakyat itu sendiri. Cita negara seperti inilah sehingga negara sampai saat ini masih sangat dibutuhkan dalam kehidupan manusia. ${ }^{4}$

Sejarah timbulnya pemikiran atau cita negara hukum itu sendiri sebenarnya sudah sangat tua, jauh lebih tua dari usia Ilmu Negara ataupun Ilmu kenegaraan. Cita negara hukum itu untuk pertama kalinya dikemukakan oleh Plato dan kemudian pemikiran tersebut dipertegas oleh Aristoteles. ${ }^{5}$

Negara sebagai bagian dari institusi yang terbesar memiliki fungsi yang besar pula dalam mewujudkan tatanan sistem yang dibangunnya agar berjalan maksimal. Dalam hal ini kemudian, secara umum adanya tujuan negara merupakan landasan dasar terbentuknya negara. Baik maupun buruk, tentunya tujuan negara tersebut menjadikan dasar negara itu ada dan terbentuk. ${ }^{6}$ Negara dibentuk oleh persekutuan masyarakat yang memiliki tujuan bersama. Dengan adanya tujuan bersama tersebut, masyarakat berkumpul dalam bentuk negara. Tujuan negara menunjukkan cita negara yang ingin diwujudkan. Tujuan negara bersifat abstrak dan idiil mengenai sesuatu yang ingin diwujudkan oleh negara. Oleh karena itu, tujuan negara berfungsi sebagai pedoman dan arahan untuk menjalankan kekuasaan negara. Pelaksanaan kekuasaan negara harus diarahkan pada terwujudnya tujuan negara. Negara merupakan instrumen yang diberikan kekuasaan oleh rakyat untuk mewujudkan apa yang menjadi tujuan mereka. ${ }^{7}$

Apabila melihat tujuan negara Indonesia maka bisa kita melihat dalam pembukaan

\footnotetext{
3 Arief Budiman, (1997), Teori Negara: Negara, Kekuasaan dan Idiologi, Jakarta: Gramedia Pustaka Utama, hlm 6

4 Ibid. hlm. 2.

5 Ni'matul Huda, Loc. Cit.

6 Muhammad Junaidi, (2016), Ilmu Negara; Sebuah Konstruksi Ideal Negara Hukum, Malang: Setara Press, hlm. 11.

7 Hufron dan Syofyan Hadi, (2015), Ilmu Negara Kontemporer, Yogyakarta: LaksBang Grafika dan Kantor Advokat "Hufron dan Rubaie" Surabaya, hlm. 35.
} 
UUD 1945 yaitu (1) Melindungi segenap bangsa Indonesia dan seluruh tumpah darah indonesia, (2) memajukan kesejahteraan umum, (3) mencerdaskan kehidupan bangsa, dan (4) ikut melaksanakan ketertiban dunia berdasarkan kemerdekaan, perdamaian abadi dan keadilan sosial. Tujuan negara yang abstrak inilah yang harus diwujudkan oleh siapapun yang berkuasa dalam suatu negara, oleh karena itu diperlukan suatu lembaga negara agar dapat mewujudkan tujuan negara tersebut

Alat-alat kelengkapan suatu negara atau yang lazim disebut sebagai lembaga negara adalah institusi-institusi yang dibentuk guna melaksanakan fungsi-fungsi negara. ${ }^{8}$ Menurut Hans kelsen, siapapun yang menjalankan suatu fungsi yang ditetapkan oleh tatanan hukum (legal order) merupakan sebuah organ. Artinya, organ negara itu tidak selalu berbentuk organik. Disamping organ yang berbentuk organik, lebih luas lagi, setiap jabatan yang ditentukan oleh hukum dapat pula disebut organ, asalkan fungsi-fungsinya itu bersifat menciptakan norma (norm creating) dan atau bersifat menjalankan norma (norm applying). ${ }^{9}$

Untuk mewujudkan apa yang menjadi tujuan negara maka diperlukan suatu lembaga negara dan kewenangan. Dalam kewenangan diatur apa saja yang menjadi kewenangan dalam suatu lembaga negara tersebut. Maka disinilah kemudian muncul hukum administrasi negara yang mana merupakan bagian dari hukum publik, yaitu hukum yang mengatur tindakan pemerintah dan mengatur hubungan antara pemerintah-warga negara atau hubungan organ pemerintah. Hukum administrasi negara memuat keseluruhan peraturan yang berkenaan dengan cara organ pemerintahan melaksanakan tugasnya. Jadi, hukum negara berisi aturan main yang berkenaan dengan fungsi organ-organ pemerintahan. ${ }^{10}$

\section{PEMBAHASAN}

Hukum administrasi negara atau hukum tata pemerintahan pada dasarnya dapat dibedakan berdasarkan tujuannya dari hukum tata negara memuat peraturan-peraturan hukum yang menentukan (tugas-tugas yang dipercayakan) kepada organ-organ pemerintah itu, menetukan tempatnya dalam negara, menentukan kedudukan terhadap warga negara, dan peraturan-peraturan hukum yang mengatur tindakan-tindakan organ pemerintahan itu. ${ }^{11}$

Hukum administrasi negara merupakan instrumen yuridis yang digunakan oleh pemerintah untuk secara aktif terlibat dalam kehidupan kemasyarakatan, dan pada sisi lain

\footnotetext{
8 Sirajuddin dan Winardi, (2015) Dasar-Dasar Hukum Tata Negara Indoensia, Malang: Setara Press, hlm. 174.

9 Jimly Asshiddiqie, (2006), Perkembangan dan Konsolidasi Lembaga Negara Pasca Reformasi, Jakarta: Konstitusi Press, hlm. 32

${ }^{10}$ Sahya Anggara, (2018), Hukum Adminstrasi Negara, Bandung: Pustaka Setia, hlm. 15.

${ }^{11}$ Ridwan, (2011), Hukum Administrasi Negara, Jakarta: RajaGrafindo Persada, hlm. 34.
} 
hukum administrasi negara merupakan hukum yang dapat digunakan oleh anggota masyarakat untuk memengaruhi dan memperoleh perlindungan dari pemerintah, jadi hukum administrasi negara memuat peraturan mengenai aktivitas pemerintah

Hukum administrasi negara atau hukum tata pemerintahan berisi peraturan-peraturan yang berkenaan dengan pemerintahan umum. Namun, tidak semua peraturan yang berkenaan dengan pemerintahan umum termasuk dalam cakupan HAN sebab ada peraturan yang menyangkut pemerintahan umum, tetapi tidak termasuk dalam HAN, melainkan masuk pada lingkup HTN. ${ }^{12}$ Hukum administrasi negara adalah seperangkat peraturan yang memungkinkan administrasi negara menjalankan fungsinya, yang sekaligus juga melindungi warga terhadap sikap tindak administrasi negara, dan melindungi administrasi negara itu sendiri. ${ }^{13}$

Prajudi Atmosudirdjo menyatakan bahwa hukum administrasi negara adalah hukum mengenai operasi dan pengendalian kekuasaan administrasi atau pengawasan terhadap penguasa administrasi. Berdasarkan definisi tersebut, hukum administrasi negara dapat dikatakan sebagai hukum yang mengatur susunan atau struktur dan kefungsian adminstrasi, sedangkan hukum hasil ciptaan adminitrasi negara adalah hukum yang menjadi pedoman dalam menjalankan atau menyelenggarakan undang-undang. ${ }^{14}$

Hukum administrasi negara merupakan bagian operasional dan pengkhususan teknis dari hukum tata negara, atau hukum konstitusi negara, atau hukum politik negara. Hukum administrasi negara sebagai hukum operasional sangat penting artinya bagi pelaksanaan tugas parapejabat administrasi negara dalam menghadapi masyarakat dan rakyat, serta penyelesaian permintaan dan kebutuhan-kebutuhannya

Selain merupakan hukum operasional dan hukum prosedural, hukum administrasi negara merupakan hukum disiplin bagi para pejabat administrasi dalam melaksanakan atau menunaikan tugas, kewajiban dan penggunaan wewenang. Hal tersebut sangat penting artinya karena para pejabat pemerintah dan administrasi dapat dibagi antara keputusan yang mempunyai daya laku hukum atau kekuatan hukum.

Seiring dengan perkembangan tugas-tugas pemerintahan, khususnya dalam ajaran welfare state, yang memberikan kewenangan luas kepada admimistrasi negara termasuk kewenangan dalam bidang legislasi, maka peraturan-peraturan hukum dalam hukum administrasi negara disamping dibuat oleh

\footnotetext{
${ }^{12}$ Op. Cit. hlm. 16.

${ }^{13}$ Sjachran Basah, (1992), Perlindungan Hukum Terhadap Sikap Tindakan Administrasi Negara, Bandung: Alumni, hlm. 4.

${ }^{14}$ Op. Cit. hlm. 20.
} 
lembaga legislatif, juga ada peraturanperaturan yang dibuat mandiri oleh administrasi negara. Dengan demikian hukum administrasi negara adalah hukum dan peraturan-peraturan yang berkenan dengan pemerintah dalam arti sempit atau administrasi negara, peraturan-peraturan tersebut dibentuk oleh lembaga legislatif untuk mengatur tindakan pemerintahan dalam hubungannya dengan warga negara, dan sebagian peraturan-peraturan itu dibentuk pula oleh administrasi negara. ${ }^{15}$

Pelaksanaan Fungsi Hukum Administrasi Negara

Istilah fungsi menurut Henc vsn Maarseven dan Ger van der Tang digunakan dalam ilmu hukum di eropa barat, yang berarti meliputi tugas atau aktivitas yang ditugaskan kepada seseorang atau suatu badan, atau peranan atau pekerjaan secara khusus (either the duty or activity assigned to a person or body, or specific role or accupation). ${ }^{16}$

Sebelum berbicara mengenai fungsi terlebih dahulu kita melihat berkaitan dengan pembagian hukum publik dan hukum privat. Hukum adminitrasi negara adalah hukum publik. Hans Kelsen menyatakan bahwa pembedaan antara hukum publik dan hukum privat adalah "a distinction fundamental to the systematization of modern legal science". ${ }^{17}$ Namun demikian Hans Kelsen mengakui sampai saat ini belum memungkinkan ditemukannya jawaban yang memuaskan mengenai perbedaan hukum publik dan hukum privat.

N.E Algra dan K. van Duyvendick membedakan hukum publik dengan hukum privat sebagai berikut : hukum publik mengatur, sesunggugnya demikian dikatakan orang, organisasi negara (hukum tata negara) dan hubungan antara penguasa dan warga negara (hukum administrasi; hukum pidana). Hukum publik mengatur campur tangan pemerintah yanga ktif dalam hidup masyarakat. Dalam hukum publik sepanjang tidak mengani lembaga negara-pengawasan adalah bahwa hubungan hukum itu ditetapkan secara sepihak oleh pemerintah. Warga negara disini terikat secara yuridis pada keputusan instansi pemerintah: penetapan pajak dilakukan oleh inspektur pajak, mengenai pemberian izin membangun serta syaratsyaratnya ditentukan oleh Walikota dan sebagainya. Juga hal mempertahankan hak dalam hukum publik itu pada umumnya adalah ditangan pemerintah. Pemerintah kota praja menentukan misalnya, apakah sesuatu bangunan yang didirikan tanpa izin harus dibongkar atau tidak. Dalam hukum pidana,

\footnotetext{
${ }^{15}$ Ridwan, Op. Cit. hlm. 37.

${ }^{16}$ A'an Efendi dan Freddy Poernomo, (2017), Hukum Administrasi, Jakarta: Sinar Grafika, hlm. 26.

${ }^{17}$ Ibid. hlm. 20.
} 
penentuan tuntutan hukum seorang tersangka berada ditangan jaksa. ${ }^{18}$

Hukum privat mengatur hubungan antar warga negara sayu sama lain. Adapun yang khas bagi hukum privat adalah pangkal tolak bahwa pada prinsipnya warga negara boleh mengatur sendiri menurut pandangannya hubungannya satu sama lain. Asas pokok otonomi warga negar ini antara lain ialah milik pribadi, kebebasan membuat statemen (dalam batas-batas tertentu, seseorang dapat membuat sendiri warisannya) dan kebebasan membuat kontrak (isi suatu persetujuan, pada dasarnya bebas dari campur tangan pembuat undang-undang). Otonomi para warga negara dalam hukum privat itu mencangkup juga bahwa kepada warga negara itu diserahkan, apakah mereka akan mempertahankan atau tidak mempertahankan haknya itu. Hal mempertahankan hak itu adalah ditangan para warga negara itu sendiri, dalan hal mana mereka memang terikat pada prosedur yang telah ditetapkan. ${ }^{19}$

Hukum publik menurut Holland adalah hukum yang mengatur hak-hak yang mana salah satu pihaknya berkaitan dengan publik, dimana negara secara langsung atau tidak langsung adalah salah satu pihaknya. Dalam hal ini kekuasaan yang melindungi hak itu dengan sendirinya berkepentingan atau dipengaruhi oleh hak tersebut. Apabila satu diantara dua subjek tidak berkaitan dengan negara maka disitu adalah hukum privat. ${ }^{20}$

Namun pendapat Holland tidak disetujui oleh Kelsen, menurut Kelsen karakteristik utama hukum publik adalah sifat penyatuan antara hakim dengan para pihak, hukum privat mewakili hubungan antara subjek secara koordinasi dan memiliki kedudukan huku yang sama. Hukum publik mewakili hubungan antara subjek yang sifatnya subordinasi dan salah satunya memiliki kedudukan yang secara hukum lebih tinggi daripada pihak lainnya. Tipikal hukum publik adalah hubungan antara negara dengan warga. $^{21}$

Pandangan tradisional membedakan hukum publik dan hukum privat bahwa hukum privat berkaitan dengan hubungan yang seimbang dan sifatnya koordinasi, sebaliknya dalam hukum publik terdapat penguasaan secara politis (private law deals with coordination and the relation between equals, whereas public law is that realm of political domination). ${ }^{22}$

Mark Ryan mengemukakan bahwa pada dasarnya hukum privat adalah cabang hukum yang mengatur hubungan antara individu satu

\footnotetext{
18 Algra N.E dan K.van Duyvendick, (1991), Pengantar Ilmu Hukum, Bandung: Bina Cipta, hlm. 162.

${ }^{19}$ Ibid, hlm. 163.

${ }^{20}$ Hans Kelsen, (2006), General Theory of Law, USA and London: Transaction Publishers, hlm. 202.

${ }^{21}$ A'an Efendi dan Freddy Poernomo, Op. Cit. hlm. 22.

${ }^{22}$ George Whitecross Paton, (1951), A Text-Book of Jurisprudence, Second Edition, Oxford: Clarendon Press, hlm 74
} 
dengan individu lainnya. Sementara itu, hukum publik adalah cabang hukum yang fokus pada sumber kekuasaaan negara, bagaimana kekuasaan itu dilaksanakan dan dikontrol, dam bagaimana dampak pelaksanaan kekuasaan tersebut terhadap individu. $^{23}$

Lebih lanjut, Mark Ryan membedakan hukum publik dengan hukum privat dalam skema sebagai berikut. ${ }^{24}$

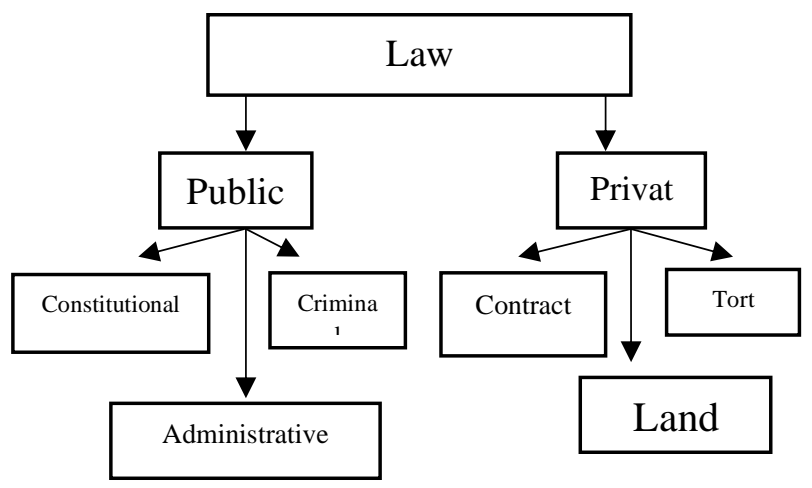

Lisa Webley dan Harriet Samuels menyatakan bahwa hukum privat mengatur hubungan antarperorangan individu, organisasi atau kelompok, dan perusahaanperusahaan. Hukum privat misalnya hukum kontrak, hukum perusahaan, dan hukum perburuhan. Sementara itu, hukum publik adalah hukum yang mengatur hubungan antara individu, organisasi atau kelompok serta perusahaan-perusahaan dengan negara dan lembaga-lembaganya. Hukum publik itu misalnya hukum pidana, hukum imigrasi, dan hukum hak asasi manusia. ${ }^{25}$

Masih menurut Lisa Webley dan Harriet Samuels, perbedaan pokok anatara hukum privat dengan hukum publik yakni hukum privat adalah istilah umum untuk smeua bidang hukum yang pada dasarnya bersifat horizontal, sedangkan hukum publik adalah istilah umum untuk semua bidang hukum yang membawa kita bersentuhan dengan kekuasaan negara dan pelaksanaanya. Hukum publik pada dasarnya bersifat vertikal.

Adanya hukum administrasi negara maka pelaksanaannya pertama, akan menjamin adanya kepastian hukum. Masalah kepastian hukum menyangkut masalah bentuk hukum, yaitu tertulis disebut hukum undang-undang, sedangkan bentuk hukum tidak tertulis disebut hukum adat atau hukum kebiasaan. Hukum undang-undang lebih banyak memberikan kepastian hukum daripada hukum adat dan hukum kebiasaan. Hal ini karena orang merasa lebih enak dan lebih nikmat bekerja dengan hukum yang tertulis daripada dengan hukum yang tidak tertulis. Van Apeldoorn dalam bukumya pengantar ilmu hukum menyebutkan pengertian kepastian hukum mempunyai dua segi sebagai berikut $:^{26}$

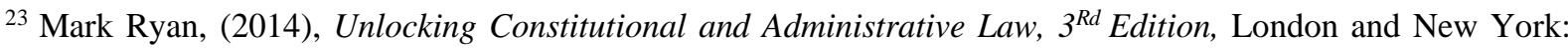
Routledge, hlm. 2.

${ }^{24}$ Ibid, hlm 1

${ }^{25}$ Lisa Webley dan Harriet Samuels, (2012), Public Law: text, Cases and materials, Second Edition, Oxford: Oxford University Press, hlm. 4.

${ }^{26}$ Sahya Anggara, (2018), Hukum Adminstrasi Negara, Bandung: Pustaka Setia, hlm. 44.
} 
a. Soal dapat ditentukan (bepaald-baarheid) hukum dalam hal-hal yang konkret. Pihak-pihak yang mencari keadilan ingin mengetahui, hukum dalam hal yang khusus, sebelum ia memulai dengan perkara

b. Kepastian hukum berarti keamanan hukum, artinya perlindungan bagi para pihak terhadap kesewenang-wenangan hakim. Jadi, kepastian hukum dapat ditentukan hukumnya (hukum tertulis) dalam hal-hal yang konkret tertentu, misalnya jual beli, pemungutan dan pembayaran pajak, dan seterusnya. Kepastian hukum ini untuk mencegah timbulnya perbuatan sewenang-wenang yang dapat dilakukan oleh siapa pun

Kedua, akan menjamin keadilan hukum. Keadilan hukum adalah keadilan yang telah ditentukan oleh undang-undang dan peraturan tertulis, misalnya keadilan dalam bidang pertanahan hukum administrasi negara yang tercantum dalam pasal 18 Undang-Undang Pokok Agraria No 5 Tahun 1960 tentang Pencabutan Hak Atas Tanah Untuk Kepentingan Umum oleh Pemerintah, tetapi pemerintah harus adil terhadap pemegang hak atas tanah itu, yaitu harus memberikan ganti kerugian yang layak. ${ }^{27}$
Ketiga, hukum administasi negara dapat berfungsi ganda. Maksud berfungsi ganda disini adalah sebagai pedoman dan ukuran. Sebagai pedoman, artinya petunjuk arah bagi perilaku manusia, yaitu menunjuk ke arah perilaku yang baik dan benar. Misalnya, pasal 19 dalam UU No 5 Tahun 1960 jo Peraturan Pemerintah No 24 Tahun 1997 Tentang Pelaksanaan Pendaftaran Tanah, digunakan sebagai pedoman bagi para pemegang hak atas tanah dan aparat Badan Pertanahan administrasi negara nasional dalam melaksanakan pendaftaran tanah di kantorkantor pertanahan hukum administrasi negara kabupaten dan kota. Adapun berfungsi sebagai ukuran, artinya untuk menilai apakah pelaksanaaan pendaftaran tanah tersebut dilakukan secara benar atau salah. Ukuran yang digunakan adalah ukuran Peraturan Pemerintah No 24 Tahun 1997, yang berisikan syarat-syarat yang harus dipenuhi dalam proses pendaftaran tanah untuk memperoleh sertifikat tanag atas nama pemegang hak atas tanah, yang dikeluarkan oleh Kepala Kantor Pertanahan hukum administasi negara setempat. ${ }^{28}$

Disamping itu menurut A.W Bradley dan K.D. Ewing, hukum administasi negara memiliki tiga fungsi. ${ }^{29}$ Pertama, hukum administrasi negara menjadikan tugas-tugas

\footnotetext{
27 Ibid. hlm. 45.

${ }^{28}$ Ibid.

${ }^{29}$ A.W. Bradley dan K.D. Ewing, Constitutional and Administrative Law, $14^{\text {th }}$ Edition, (Edinburg Gate: Pearson Education, 2007), hlm. 657-658.
} 
pemerintahan dapat dijalankan. Badan-badan pemerintahan diciptakan oleh hukum dan dilengkapi dengan kekuasaan untuk dilaksanakan atas nama negara dan kepentingan umum (enable teh task of goverment to be performed). Kedua, fungsi hukum administrasi negara adalah mengatur hubungan antara badan-badan publik, misalnya antara menteri dengan pemerintah lokal atau antar pemerintah lokal satu dengan lainnya (to govern teh relations between public agencies, for example, between a minister and a local authority or between two local authorities). Ketiga, hukum adminstrasi mengatur hubungan antara badan-badan publik dengan individu atau badan-badan hukum privat (to govern the relations between a public agency and those individuals or private bodies over whose affairs the agency is entrusted with power).

Wade menyatakan bahwa tujuan utama hukum administrasi negara adalah untuk menjaga agar kekuasaan pemerintah berjalan sesuai dengan batas-batasnya dan sekaligus melindungi warga negara terhadap penyalahgunaan kekuasaan oleh pemerintah (to keep the powers of goverment within their legal bounds, so as to protect the citizen against their abuse. The powerful engines of authority must be prevented from running amok). ${ }^{30}$ Alfred C. Aman Jr pun menyatakan bahwa hukum administrasi negara berfungsi untuk memaksimalkan perlindungan terhadap masyarakat dari tindakan kesewenangwenangan pemerintah (to maximise protections from govermental action). ${ }^{31}$

G. Faltoe menyatakan bahwa fungsi utama hukum administrasi negara adalah sebagai kontrol hukum bagi pelaksanaan fungsi pemerintahan dan untuk menjamin bahwa pemerintah bertindak sesuai dengan wewenangnya atau tidak menyalahgunakan wewenangnya (to exert reasonable legal control over the way in which administrative authorities exercise their functions in order to ensure that these authorities do not exceed or abuse their powers). ${ }^{32}$

Aberham Yohanes dan Desat G/Michael, fungsi utama hukum administrasi negara adalah concerned with the control of power. Todd Rakoff menyatakan bahwa fungsi hukum administrasi negara adalah mengontrol tindakan pemerintah (to controls how goverment operates). ${ }^{33}$ Demikian dengan Sunita Zulpuri yang menyatakan bahwa hukum administrasi negara provides an instruments of control of exercise of administrative power. ${ }^{34}$

\footnotetext{
${ }^{30}$ H.W.R Wade, (1982), Administrative Law. Fifth Edition, (Oxford: English Language Book Society/Oxford University Press, hlm 5

31 Alfred C. Aman, (1997), Administrative law For a New Century, Oxford: hart Publisihing, hlm. 92.

${ }^{32}$ G. Feltoe, (2012), A Guide to Administrative and Local Goverment Law in Zimbabwe, __ _ Tanpa Penerbit, hlm. 2.

${ }^{33}$ A'an Efendi dan Freddy Poernomo, (2017), Hukum Administrasi, Jakarta: Sinar Grafika, hlm. 27.

${ }^{34}$ Ibid.
} 
Selanjutnya Peer Leyland dan Tery Woods merinci funsgi hukum adminitrasi negara sebagai berikut $:^{35}$

a. Hukum administrasi negara menjalankan fungsi kontrol untuk mencegah penyalahgunaan wewenang oleh pemerintah

b. Hukum adminitrasi negara memiliki fungsi perintah (command function) yang dibuat oleh badan-badan publik untuk menjalankan kewajibannya berdasarkan undang-undang, termasuk pelaksanaan diskresi

c. Hukum adminitrasi negara mewujudkan prinsip-prinsip untuk emudahkan pelaksanaan pemerintahan yang baik: misalnya untuk menjamin bahwa peraturan yang fairness dilaksanakan

d. Hukum administrasi negara menetapkan akuntabilitas dan keterbukaan, termasuk peran serta oleh para pihak dan individu yang berkepentingan dalam pelaksanaan pemerintahan

e. Hukum administrasi negara menyediakan ganti kerugian untuk keluhan terhadap badan-badan publik.

Disamping itu kita juga melihat aturan dalam Undang-Undang No 30 Tahun 2014 Tentang Administrasi Pemerintahan dalam konsideran menimbang disebutkan bahwa untuk menyelesaikan permasalahan dalam penyelenggaraan pemerintahan, pengaturan mengenai administrasi pemerintahan diharapkan dapat menjadi solusi dalam memberikan pelindungan hukum, baik bagi warga masyarakat maupun pejabat pemerintahan.

Dan untuk mewujudkan pemerintahan yang baik, khususnya bagi pejabat pemerintahan, undang- undang tentang administrasi pemerintahan menjadi landasan hukum yang dibutuhkan guna mendasari keputusan dan/atau tindakan pejabat pemerintahan untuk memenuhi kebutuhan hukum masyarakat dalam penyelenggaraan pemerintahan.

\section{KESIMPULAN}

Keberadaan hukum administrasi negara dalam konsep negara hukum adalah mutlak keberadaannya. Dengan adanya hukum administasi negara yang kemudian melahirkan asas legalitas yang berarti setiap tindakan hukum Pemerintah harus berdasarkan pada peraturan perundangundangan yang berlaku atau setiap tindakan hukum pemerintahan harus berdasarkan pada kewenangan yang diberikan oleh peraturan perundang-undangan, akan terjamin keadilan bagi masyarakat. Hubungan antara warga negara dengan pemerintah yang sejatinya tidak sejajar maka memberikan perlindungan bagi masyarakat atas tindakan hukum

\footnotetext{
35 Ibid, hlm. 28.
} 
pemerintah adalah keharusan demi Jimly Asshiddiqie, 2006, Perkembangan dan terlindunginya HAM mereka.

\section{DAFTAR PUSTAKA}

\section{Peraturan Perundang-Undangan}

Undang-Undang No 30 tahun 2014 Tentang Administrasi Pemerintahan

\section{Buku}

A.W. Bradley dan K.D. Ewing, 2007, Constitutional and Administrative Law, $14^{\text {th }}$ Edition, Edinburg Gate: Pearson Education

A'an Efendi dan Freddy Poernomo, 2017, Hukum Administrasi, Jakarta: Sinar Grafika

Alfred C. Aman, 1997, Administrative law For a New Century, Oxford: hart Publisihing

Algra N.E dan K.van Duyvendick, 1991, Pengantar Ilmu Hukum, Bandung: Bina Cipta

Arief Budiman, 1997, Teori Negara ; Negara, Kekuasaan dan Idiologi, Jakarta: Gramedia Pustaka Utama

G. Feltoe, 2012, A Guide to Administrative and Local Goverment Law in Zimbabwe, Tanpa Kota: Tanpa Penerbit

George Whitecross Paton, 1951, A Text-Book of Jurisprudence, Second Edition, Oxford: Clarendon Press

H.W.R Wade, 1982, Administrative Law. Fifth Edition, Oxford: English Language Book Society/Oxford University Press,

Hans Kelsen, 2006, General Theory of Law, USA and london: Transaction Publishers

Hufron dan Syofyan Hadi, 2015, Ilmu Negara Kontemporer, Yogyakarta: LaksBang Grafika dan Kantor Advokat " Hufron dan rubaie" surabaya, 2015), hlm 35

I Gede Pantja Astawa, 2015, Memahami Ilmu Negara dan Teori Negara, Bandung: PT Refika Aditama
Konsolidasi Lembaga Negara Pasca Reformasi, Jakarta: Konstitusi Press

Lisa Webley dan Harriet Samuels, 2012, Public Law: text, Cases and materials, Second Edition, Oxford: Oxford University Press

Mark Ryan, 2014, Unlocking Constitutional

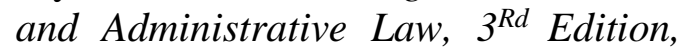
London and New York: Routledge

Muhammad Junaidi, 2016, Ilmu Negara; Sebuah Konstruksi Ideal Negara Hukum, Malang: Setara Press

Ni'matul Huda, 2005, Negara Hukum, Demokrasi dan Judicial Review, Yogyakarta: UII Press

Ridwan, 2011, Hukum Administrasi Negara, Jakarta: PT RajaGrafindo Persada

Sahya Anggara, 2018, Hukum Adminstrasi Negara, Bandung: CV Pustaka Setia

Sirajuddin dan Winardi, 2015, Dasar-Dasar Hukum Tata Negara Indoensia, Malang: Setara Press

Sjachran Basah, 1992, Perlindungan hukum terhadap sikap tindakan administrasi negara, Bandung: Alumn 